\title{
UPAYA MENINGKATKAN RASA PERCAYA DIRI SISWA DALAM MENGEMUKAKAN PENDAPAT MELALUI LAYANAN BIMBINGAN KELOMPOK
}

\author{
Nurlaily \\ SMP 21 Pekanbaru \\ e-mail: nurlaily@yahoo.co.id
}

\begin{abstract}
Based on the results of interviews with teachers mentors about the problems that often occur in students in SMP Negeri 21 Pekanbaru in obtaining information that: The lack of mutual understanding of students. This includes a lack of trust between students, lack of openness from students to teachers and sometimes also among fellow students so that often miscommunication among students who became one of the triggers of contention. Students are less able to express their opinions both to teachers and friends. Subjects in this study were students Class IX.I SMP Negeri 21 Pekanbaru Lesson Year 2014-2015 with the number of students as many as 37 people. The form of research is action research counseling guidance services. The instrument of this research is data in the form of observation sheet of teacher activity and Student Self Confidence in Opinion Opinion. Based on the results of the analysis and discussion as presented in chapter IV can be concluded that with the Group Guidance Services can improve Student Confidence in Student Expose Class IX.1 SMP Negeri 21 Pekanbaru. Before the action shows Student Confidence in Student Opinion is still classified as "Less" with a score of 44.9 is at the interval of 30-49. In cycle I shows that Student Confidence in Student Opinion is still classified as "Medium" with the value of 60.0 is in the interval 50 - 69. While in the second cycle increased to 83.8 with the category "Good" is at the interval 70-89.
\end{abstract}

Keywords: counseling guidance services, Student Self Confidence in Opinion

Berdasarkan hasil wawancara dengan guru pembimbing tentang permasalahan yang sering terjadi pada siswa di SMP Negeri 21 Pekanbaru di peroleh informasi bahwa : Kurang adanya saling memahami pada diri siswa. Hal ini mencakup kurang adanya sikap percaya antar siswa, kurang keterbukaan dari siswa terhadap guru dan terkadang juga antar sesama siswa sehingga sering terjadi miskomunikasi antarsiswa yang menjadi salah satu pemicu pertengkaran. Siswa kurang mampu mengemukakan pendapatnya baik terhadap guru maupun temannya. Subjek dalam penelitian ini adalah siswa Kelas IX.1 SMP Negeri 21 Pekanbaru Tahun Pelajaran 2014-2015 dengan jumlah siswa sebanyak 37 orang. Bentuk penelitian adalah penelitian tindakan layanan bimbingan konseling. Instrumen penelitian ini adalah data berupa lembar observasi aktivitas guru dan Rasa Percaya Diri Siswa dalam Mengemukakan Pendapat. Berdasarkan hasil analisis dan pembahasan seperti disampaikan pada bab IV dapat disimpulkan bahwa dengan Layanan Bimbingan Kelompok dapat meningkatkan Rasa Percaya Diri Siswa dalam Mengemukakan Pendapat Siswa Kelas IX.1 SMP Negeri 21 Pekanbaru. Pada sebelum tindakan menunjukkan Rasa Percaya Diri Siswa dalam Mengemukakan Pendapat siswa masih tergolong "Kurang” dengan memperoleh nilai 44.9 berada pada interval 30-49. Pada siklus I menunjukkan bahwa Rasa Percaya Diri Siswa dalam Mengemukakan Pendapat siswa masih tergolong "Sedang" dengan memperoleh nilai 60.0 berada pada interval 50 - 69. Sedangkan pada siklus II meningkat menjadi 83.8 dengan kategori "Baik" berada pada interval 70-89.

Kata Kunci : layanan bimbingan konseling, Rasa Percaya Diri Siswa dalam Mengemukakan Pendapat 


\section{PENDAHULUAN}

Saat ini pendidikan bukan lagi diterjemahkan sebagai bentuk pembelajaran formal semata yang ditujukan untuk mengasah kemampuan berpikir saja. Pendidikan lebih diarahkan untuk membantu peserta didik menjadi mandiri dan terus belajar selama rentang kehidupan yang dijalaninya sehingga memperoleh hal-hal yang membantu menghadapi tantangan dalam menjalani kehidupan. Pendidikan itu sendiri dapat diartikan sebagai upaya mencerdaskan bangsa, menanamkan nilai-nilai moral dan agama, membina kepribadian, mengajarkan pengetahuan, melatih kecakapan, keterampilan, memberikan bimbingan, arahan, tuntutan, teladan dan disiplin. Pendidikan dapat dilakukan dalam berbagai bentuk, namun dalam lingkup formal, pendidikan dilakukan oleh sebuah lembaga yang dinamakan sekolah. Sekolah merupakan lembaga pendidikan formal yang secara sistematik melaksanakan kegiatan bimbingan, pengajaran dan latihan dalam rangka membantu siswa agar mampu mengembangkan potensinya baik yang menyangkut aspek moral-spiritual, intelektual, emosional maupun sosial.

Di lingkungan sekolah, guru mengemban tugas untuk menstimulus dan membina perkembangan intelektual siswa serta membina pertumbuhan nilai-nilai, sikap, dan perilaku dalam diri siswa. Sekolah juga merupakan lingkungan yang khusus mengubah tingkah laku secara menetap dalam hubungan seluruh perkembangan kepribadian sebagai anggota masyarakat.

Pada masa remaja inilah siswa harus memiliki kepercayaan diri yang cukup untuk melangkah karena aspek kepercayaan diri ini merupakan aspek yang sangat berpengaruh dalam membentuk kepribadian siswa. Kepercayaan diri sangat dibutuhkan oleh setiap siswa, karena aspek kepercayaan diri ini mempengaruhi dalam setiap proses belajarnya, baik dalam belajar di kelas, di rumah atau di manapun.

Seperti yang dikatakan oleh Angelis (2005 : 20) "rendah diri, rasa malu, rasa takut melakukan sesuatu, frustrasi, perasaan cemas atau bahkan sikap agresif merupakan indikator dari kurang atau tidak adanya kepercayaan diri”. Gejala tidak percaya diri ini umumnya dianggap sebagai gangguan ringan karena tidak menimbulkan masalah besar. Disadari atau tidak, sebagian besar orang ternyata mengalami gejala tidak percaya diri seperti ini. Sikap seseorang yang menunjukkan dirinya tidak percaya diri, antara lain di dalam berbuat sesuatu, terutama dalam melakukan sesuatu yang penting dan penuh tantangan, selalu dihinggapi keraguan-raguan, mudah cemas, tidak yakin, cenderung menghindar, tidak punya inisiatif, mudah patah semangat, tidak berani tampil di depan orang banyak, dan gejala kejiwaan lainnya yang menghambatnya untuk melakukan sesuatu.

Ketidakpercayaan diri dapat dipengaruhi beberapa faktor yaitu faktor dari dalam diri individu itu sendiri dan faktor dari lingkungan individu. Faktor dari dalam diri individu adalah rasa benci, rasa takut, kecemasan, tidak dapat menerima kenyataan hidup dan tidak dapat mengaktualisasikan kemampuan yang ada pada dirinya. Faktor lingkungan yang mempengaruhi kepercayaan diri antara lain faktor keluarga, sekolah, teman sebaya dan masyarakat. Faktor dari dalam diri individu dan faktor dari lingkungan individu merupakan sumber permasalahan bagi individu yang mengalami ketidakpercayaan diri. Meskipun kepercayaan diri diidentikkan dengan kemandirian, orang yang percaya dirinya tinggi umumnya lebih mudah terlibat secara pribadi dengan orang lain dan lebih berhasil dalam hubungan antar personal.

Masalah tersebut merupakan indikator dari kurang atau tidak adanya kepercayaan diri. Hal ini sudah tentu akan menghambat proses belajar para siswa untuk mencapai hasil yang optimal. Apabila siswa yang tidak memiliki rasa percaya diri yang baik maka dapat dimungkinkan siswa tersebut akan mengalami gagal belajar dan hal ini dapat menghambat pencapaian tujuan pendidikan. Kegagalan dalam belajar sangat mempengaruhi kepribadian siswa yang terbentuk karena tidak dapat mencapai apa yang diharapkan.

Berdasarkan hasil wawancara dengan guru pembimbing tentang permasalahan yang sering terjadi pada siswa di SMP Negeri 21 Pekanbaru di peroleh informasi bahwa : 
a. Kurang adanya saling memahami pada diri siswa. Hal ini mencakup kurang adanya sikap percaya antar siswa, kurang keterbukaan dari siswa terhadap guru dan terkadang juga antar sesama siswa sehingga sering terjadi miskomunikasi antarsiswa yang menjadi salah satu pemicu pertengkaran.

b. Siswa kurang mampu mengemukakan pendapatnya baik terhadap guru maupun temannya.

Berdasarkan hasil wawancara dengan guru kelas tentang rasa percaya diri siswa dalam mengemukakan pendapat dari guru kelas di SMP Negeri 21 Pekanbaru diperoleh informasi bahwa :

Siswa belum mampu mengkomunikasikan pikiran dan perasaan secara tepat dan jelas, dan siswa tidak memiliki perasaan percaya diri. Hal ini ditunjukkan salah satunya saat sedang berlangsung proses belajar mengajar di kelas, ataupun ketika ada mata pelajaran secara kelompok yang harus dipresentasikan dengan diskusi, siswa belum ada yang mau bertanya atau menyampaikan pendapatnya sehingga terkadang meresahkan para guru mata pelajaran karena mereka menjadi ragu terhadap pemahaman para siswa terhadap materi pelajaran yang telah disampaikan

Berdasarkan hasil pengamatan di SMP Negeri 21 Pekanbaru gejala yang diperoleh yaitu (1) siswa tidak berani mengajukan pertanyaan atau pendapatnya kepada guru, (2) tidak bersedia tampil di depan kelas, (3) berbicara gugup, (4) menghindarkan diri ketika akan ditanya oleh guru. Hal ini diperkuat dengan perilaku mereka seperti ; tidak mau maju kedepan kelas, tidak berani tampil bila berhadapan dengan orang banyak, dan tidak mau megajukan pendapatnya di dalam kelompok, siswa mengalami kesulitan dalam berkomunikasi dengan orang lain baik dalam proses belajar di dalam kelas maupun dalam suasana informal di luar kelas.

Salah satu kemungkinan besar yang menjadi penyebab terjadinya kesulitan komunikasi adalah rasa tidak percaya diri, gangguan fisik pada siswa, keadaan lingkungan sekitar tempat tinggal. Ketidak percayaan diri siswa yang menyebabkan siswa sulit untuk diajak berkomunikasi diantaranya adalah takut menerima tanggapan atau penilaian negatif dari komunikan atau orang yang menerima pesan, dan sulit berkonsentrasi. Fenomena yang tampak adalah ketika siswa masuk dalam suasana diskusi dalam kelas, siswa sulit untuk diajak berkomunikasi karena merasa tidak percaya diri atas gagasan yang dimilikinya karena takut salah dll, sehingga menjadikan diskusi dalam kelas ini membosankan dan tidak ada hasil yang di dapat dalam diskusi ini. Ketika proses belajar mengajar jika seorang Bapak/Ibu guru mengajar semua siswa di dalam kelas pasif, tidak ada yang mau bertannya, dan takut bertanya ketika tidak mengerti. Dari emaparan di atas dapat disimpulkan bahwa kepercayaan diri sangat diperlukan, salah satunya untuk dapat berkomunikasi dan berinteraksi dengan lingkungan dan teman sebayanya.

Berdasarkan pemaparan uraian di atas, dalam upaya memberikan bantuan untuk meningkatkan kepercayaan diri siswa peneliti akan meningkatkan kepercayaan diri siswa melalui layanan bimbingan kelompok. Bimbingan dan konseling merupakan salah satu komponen sekolah dan mengemban tugas pendidikan karakter. Pelaksanaan bimbingan dan konseling tidak bisa lepas dari fungsi dan tujuan pendidikan. Pelaksanaan bimbingan dan konseling di sekolah dilakukan oleh konselor sekolah sebagaimana telah diakui dalam undang-undang sistem pendidikan nasional Tahun 2003 pasal 1. Melalui layanan bimbingan dan konseling yang dilakukan konselor dapat membantu siswa mencapai individu yang memiliki Rasa Percaya Diri Siswa dalam Mengemukakan Pendapat. Layanan bimbingan dan konseling yang dilakukan di sekolah meliputi layanan orientasi, informasi, penguasaan konten, penempatan penyaluran, bimbingan kelompok, bimbingan kelompok, konsultasi, dan layanan mediasi. Dalam memberikan layanan ada yang bersifat secara pribadi, klasikal, dan bersifat kelompok.

Bimbingan kelompok merupakan sebagai media dalam upaya membimbing individu yang bertujuan untuk mengembangkan perasaan berfikir, persepsi, wawasan, dan sikap terarah kepada tingkah laku yang diinginkan dengan memanfaatkan dinamika kelompok. Melalui bimbingan kelompok siswa mendapat berbagai informasi tentang sikap mandiri dan melalui dinamika kelompok siswa dapat belajar berinteraksi dengan anggota kelompok yang mempunyai pengetahuan, pengalaman, gagasan tentang sikap mandiri yang berbeda-beda. Berkembangnya wawasan, perasaan, berfikir, dan berpersepsi dari 
siswa dalam kegiatan layanan bimbingan kelompok akan mendorong siswa untukdapat menyelesaikan masalahnya, mampu mengarahkan dirinya, memiliki pandangan hidup sendiri, mampu mengatur kehidupannya sendiri, serta berani menanggung segala akibat dari tindakan yang dilakukannya, dengan kata lain siswa dapat mengembangan Rasa Percaya Diri Siswa dalam Mengemukakan Pendapat serta mungkin sekali Rasa Percaya Diri Siswa dalam Mengemukakan Pendapat siswa akan meningkat.

Peneliti merasa tertarik dan ingin melakukan suatu penelitian tindakan sebagai upaya dalam melakukan perbaikan terhadap pembelajaran dengan judul "Upaya Meningkatkan Rasa Percaya Diri Siswa dalam Mengemukakan Pendapat Melalui Layanan Bimbingan Kelompok di Kelas IX.1 SMP Negeri 21 Pekanbaru".

\section{METODE}

Sebagai subjek dalam penelitian ini adalah siswa Kelas IX.1 SMP Negeri 21 Pekanbaru Tahun Pelajaran 2014-2015 dengan jumlah siswa sebanyak 37 orang. Sedangkan yang menjadi objek dalam penelitian ini adalah Rasa Percaya Diri Siswa dalam Mengemukakan Pendapat siswa dan Layanan Bimbingan Kelompok.

Adapun waktu penelitian ini direncanakan selama empat bulan, terhitung mulai dari bulan Desember 2014. Agar penelitian tindakan Layanan Bimbingan Kelompok ini berhasil dengan baik tanpa hambatan yang mengganggu kelancaran penelitian, maka peneliti menyusun tahapan-tahapan yang dilalui dalam penelitian tindakan Layanan Bimbingan Kelompok, yaitu:

a. Perencanaan/persiapan tindakan

b. Pelaksanaan tindakan

c. Observasi

d. Refleksi

Setelah data terkumpul melalui observasi, data tersebut diolah dengan menggunakan rumus persentase, ${ }^{1}$ yaitu sebagai berikut :

$$
p=\frac{\mathrm{F}}{\mathrm{N}} \times 100 \%
$$

Keterangan:

$\mathrm{F} \quad=$ Jumlah skor perolehan

$\mathrm{N}=$ Number of Cases (Jumlah skor maksimal)

$\mathrm{P} \quad=$ Angka persentase

$100 \%$ = Bilangan Tetap

\section{HASIL DAN PEMBAHASAN}

Berdasarkan hasil observasi pada sebelum tindakan dapat diketahui bahwa Rasa Percaya Diri Siswa dalam Mengemukakan Pendapat siswa masih rendah, hal ini dapat diketahui sebelum tindakan Rasa Percaya Diri Siswa dalam Mengemukakan Pendapat siswa berada pada kategori rendah dengan ratarata persentase $44.9 \%$ berada pada interval $0-40 \%$. Siklus pertama pertemuan pertama yang menunjukkan bahwa tingkat Rasa Percaya Diri Siswa dalam Mengemukakan Pendapat siswa secara klasikal hanya mencapai rata-rata persentase $51.4 \%$ berada pada interval $40 \%-55 \%$ tergolong cukup tinggi dan pada pertemuan kedua Rasa Percaya Diri Siswa dalam Mengemukakan Pendapat siswa secara klasikal

${ }^{1}$ Anas Sudjono, Pengantar Statistik Pendidikan, Jakarta : PT. Raja Grafindo Persada, 2004. hln. 43 
mencapai rata-rata persentase $60.0 \%$, berada pada interval $40-55 \%$ tergolong cukup tinggi. Sedangkan pada siklus II pertemuan pertama terjadi peningkatan dengan perolehan nilai rata-rata secara klasikal 73.0\% berada pada interval 56\%-75\% tergolong tinggi dan pada pertemuan kedua secara klasikal memperoleh nilai rata-rata persentase $83.8 \%$, berada pada interval $76-100 \%$ dengan kategori sangat tinggi. Perbandingan antara Rasa Percaya Diri Siswa dalam Mengemukakan Pendapat pada Data Awal, Siklus I dan Siklus II secara jelas dapat dilihat pada tabel berikut ini:

GAMBAR 1

GAMBAR HISTOGRAM RASA PERCAYA DIRI SISWA DALAM MENGEMUKAKAN PENDAPAT SISWA DATA AWAL, SIKLUS I DAN SIKLUS II

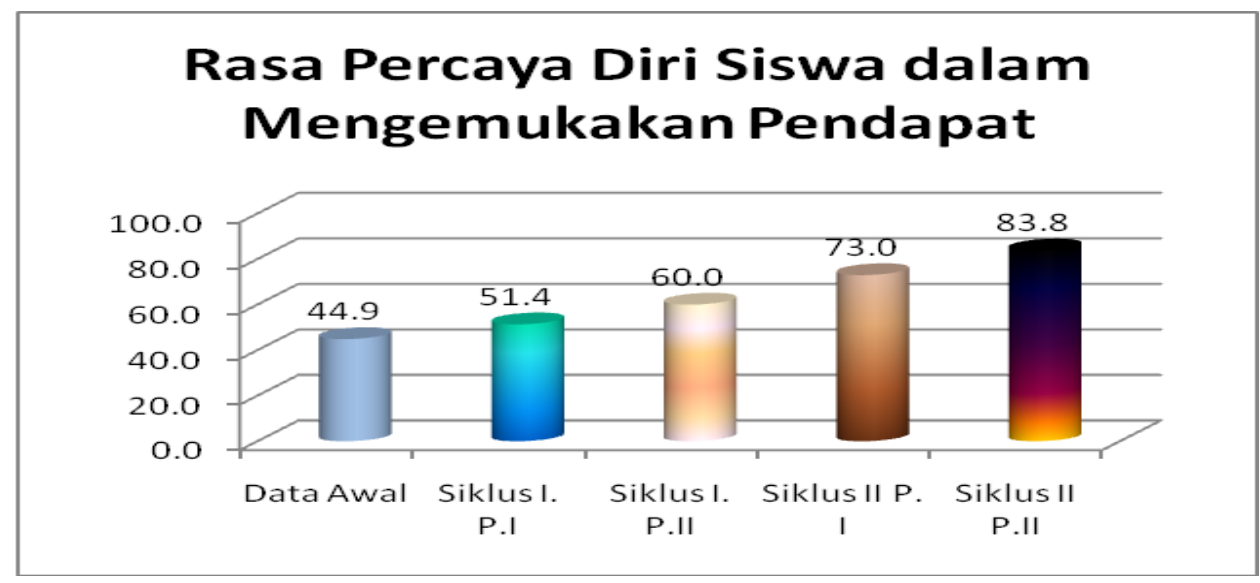

Berdasarkan pembahasan di atas maka dapat disimpulkan bahwa kelemahan-kelemahan Layanan Bimbingan Kelompok sebelum tindakan dan siklus I, dapat diperbaiki pada siklus II hingga mencapai tingkat sangat sempurna ternyata dapat meningkatkan Rasa Percaya Diri Siswa dalam Mengemukakan Pendapat siswa. Melalui perbaikan proses penerapan Layanan Bimbingan Kelompok pada siklus II.

Meningkatnya Rasa Percaya Diri Siswa dalam Mengemukakan Pendapat siswa pada siklus II dibandingkan dengan siklus sebelumnya membuktikan bahwa dengan penerapan Layanan Bimbingan Kelompok dapat mningkatkan Rasa Percaya Diri Siswa dalam Mengemukakan Pendapat siswa Kelas IX.1 SMP Negeri 21 Pekanbaru tahun pelajaran 2015-2016. Dari hasil penelitian dan pembahasan seperti telah duraikan di atas menjelaskan bahwa "Dengan penerapan Layanan Bimbingan Kelompok untuk meningkatkan Rasa Percaya Diri Siswa dalam Mengemukakan Pendapat siswa Kelas IX.1 SMP Negeri 21 Pekanbaru" dapat diterima.

\section{KESIMPULAN}

Berdasarkan hasil analisis dan pembahasan seperti disampaikan pada bab IV dapat disimpulkan bahwa dengan Layanan Bimbingan Kelompok dapat meningkatkan Rasa Percaya Diri Siswa dalam Mengemukakan Pendapat Siswa Kelas IX.1 SMP Negeri 21 Pekanbaru. Hal ini dapat dibuktikan dari :

1. Aktivitas Guru

Dari hasil observasi pada siklus pertama yang menunjukkan bahwa aktivitas guru pada siklus I pertemuan pertama memperoleh nilai 47 dengan kategori cukup sempurna, pertemuan kedua memperoleh nilai 65 dengan kategori cukup sempurna, siklus kedua pertemuan pertama memperoleh nilai 77 dengan kategori sempurna dan pertemuan kedua memperoleh nilai 89 dengan kategori sangat 
sempurna.

2. Rasa Percaya Diri Siswa dalam Mengemukakan Pendapat

Pada sebelum tindakan menunjukkan Rasa Percaya Diri Siswa dalam Mengemukakan Pendapat siswa masih tergolong "Kurang" dengan memperoleh nilai 44.9 berada pada interval 30-49. Pada siklus I menunjukkan bahwa Rasa Percaya Diri Siswa dalam Mengemukakan Pendapat siswa masih tergolong "Sedang" dengan memperoleh nilai 60.0 berada pada interval 50 - 69. Sedangkan pada siklus II meningkat menjadi 83.8 dengan kategori "Baik" berada pada interval 70-89.

\section{SARAN}

Bertolak dari kesimpulan dan pembahasan hasil penelitian di atas, peneliti mengajukan beberapa saran, yaitu:

a. Bagi guru

Untuk meningkatkan Rasa Percaya Diri Siswa dalam Mengemukakan Pendapat di sekolah diharapkan kepada Guru BK dapat menerapkan Layanan Bimbingan Kelompok.

b. Bagi Sekolah

Kepada kepala sekolah perlu memantau dan membina terhadap dampak kegiatan Penelitian Tindakan Layanan Bimbingan Konseling (PTLBK), sebagai bahan penilaian kemajuan yang telah dicapai, sehingga apa yang ditemukan pada PTLBK dapat diimplementasikan dalam pelaksanaan pembelajaran di sekolah.

c. Bagi siswa

Untuk siswa agar lebih serius dalam belajar agar Rasa Percaya Diri Siswa dalam Mengemukakan Pendapat siswa lebih bagus.

\section{DAFTAR PUSTAKA}

[1]. Angelis. 2005. Confidence: Percaya Diri Sumber Sukses dan Kemandirian. Jakarta: Purwa Suara Latipun, 2008. Psikologi Konseling, Malang: UMM

[2]. Natawidjaja, 2009. Bimbingan kelompok, Konsep Dasar dan Pendekatan, Bandung: Rizqi

[3]. Prayitno. 1995. Layanan Bimbingan dan Bimbingan kelompok (dasar dan profil). Jakarta: Ghalia Indonesia.

[4]. Supriyo, 2008. Studi Kasus Bimbingan dan Konseling. Semarang: Nieuw Setapak.

[5]. Saputra, T. (2017). The relationship between family functioning and juvenile delinquency at SMKN 4 Pekanbaru. Jurnal Psikologi Pendidikan dan Konseling: Jurnal Kajian Psikologi Pendidikan dan Bimbingan Konseling, 21-26. 